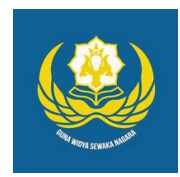

Jurnal Analogi Hukum

Journal Homepage: https://ejournal.warmadewa.ac.id/index.php/analogihukum

\title{
Perlindungan Hukum Bagi Penumpang Angkutan Umum Trans Serasi Tabanan
}

\author{
I Gusti Agung Tria Masdiana Putra*, I Nyoman Putu Budiartha dan Ni Made Puspasutari Ujianti
}

Fakultas Hukum, Universitas Warmadewa, Denpasar, Bali-Indonesia

*masdianaputra@gmail.com

How To Cite:

Putra, I. G. A. T. M., Budiartha, I. N. P., \& ., Ujianti, N. M. P. (2020). Perlindungan Hukum Bagi Penumpang Angkutan Umum Trans Serasi Tabanan. Analogi Hukum. 2(1). 42-46. Doi: http://dx.doi.org/10.22225/.2.1.1609.42-46

\begin{abstract}
Transport is a facility that functions as the transfer of goods or people from one place to another. Seen in the community environment, in fact there are still a number of transporters who carry out actions outside standardization as well as carrying passengers in excess of the prescribed capacity, this has violated traffic rules and violated the rules on consumer protection, In addition, due to the neglected passenger rights and a lack of awareness of passengers in terms of security and comfort as service users, the authors are interested in lifting the title and conducting research on legal protection for public transport passengers at Trans Serasi Tabanan. The problems of this research are; 1. How is legal protection for public transport passengers as consumers of transportation facilities? and 2. What is the responsibility of the carrier for errors that result in losses for public transport passengers? This research is categorized into empirical research, because it wants to know the form of legal protection for Trans Serasi Tabanan passengers. From the results of the research and discussion show that the lack of awareness of the transporters in paying attention to the safety and comfort of passengers and passengers is also less aware of the importance of their rights to obtain security and comfort in using public transportation services so that their rights as service users are ignored.This legal research is expected for the transporters to pay more attention to the comfort and safety of passengers and the passengers are also more selective in using public transport services so that there are no events that can cause harm in any form.
\end{abstract}

Keywords: Legal Protection; Passenger; Public transportation

\begin{abstract}
Abstrak-Angkutan merupakan sarana yang berfungsi sebagai pemindah barang ataupun orang dari suatu tempat ke tempat lainnya. Dilihat dalam lingkungan masyarakat, kenyataanya masih ada beberapa oknum pengangkut yang melakukan tindakan diluar standarisasi seperti halnya mengangkut penumpang dalam jumlah melebihi kapasitas yang telah ditetapkan, hal ini sudah melanggar tata tertib dalam berlalu lintas serta melanggar tata tertib tentang perlindungan konsumen. Selain itu, adanya hak-hak penumpang yang terabaikan serta kurangnya kesadaran penumpang dalam hal keamanaan dan kenyamanan sebagai pengguna jasa, maka penulis tertarik mengangkat judul dan melakukan penelitian mengenai perlindungan hukum terhadap penumpang angkutan umum Trans Serasi Tabanan. Adapun permasalahan dari penelitian ini yakni; 1. Bagaimanakah upaya perlindungan hukum terhadap penumpang angkutan umum sebagai konsumen fasilitas transportasi? serta 2. Bagaimanakah tanggung jawab pihak pengangkut terhadap kesalahan yang mengakibatkan kerugian bagi penumpang angkutan umum? Penelitian ini dikategorikan ke dalam penelitian empiris, dikarenakan ingin mengetahui bentuk perlindungan hukum bagi penumpang Trans Serasi Tabanan. Dari hasil penelitian dan pembahasan menunjukkan bahwa kurangnya kesadaran dari pihak pengangkut dalam memperhatikan keamanan dan kenyamanan penumpang serta dari pihak penumpang juga kurang menyadari pentingnya hak-hak mereka untuk memperoleh keamanan dan kenyamanan dalam menggunakan jasa angkutan umum sehingga hak mereka sebagai pengguna jasa pun terabaikan. Penelitian hukum ini diharapkan bagi pengangkut agar lebih memperhatikan kenyamanan dan keamanan penumpang serta pihak penumpang juga lebih selektif dalam menggunakan jasa transportasi angkutan umum agar tidak adanya kejadian yang dapat menimbulkan kerugian dalam bentuk apapun.
\end{abstract}

Kata Kunci: Perlindungan Hukum; Penumpang ; Angkutan Umum

Jurnal Analogi Hukum, Volume 2, Nomor 1, 2020. CC-BY-SA 4.o License 


\section{Pendahuluan}

Peranan transportasi umum dalam masyarakat sangatlah penting, menyadari hal tersebut maka perlu adanya peningkatan dalam penyediaan lalu lintas dan angkutan jalan dalam sistem transportasi umum yang nantinya mampu mewujudkan sarana transportasi umum yang sesuai dengan tingkat kebutuhan lalu lintas serta dapat menciptakan pelayanan yang nyaman, aman, tertib, lancar, teratur dan cepat serta adanya penekanan biaya pada angkutan umum, yang nantinya dapat dijangkau oleh masyarakat.

Kabupaten Tabanan memiliki wilayah dengan luas sebesar 839,33 km2 dan jumlah penduduk sebanyak 441,0 ribu jiwa, serta kepadatan penduduk mencapai 525 jiwa per $\mathrm{km} 2$ pada tahun 2017 , dengan laju pertumbuhan alaminya sebesar $0,621 \%$ dari tahun 2010 (https://tabanankab.bps.go.id/

publication/2018/08/16/468aa965d1fl fad51048 4df3/kabupaten-tabanan-dalam-angka2018.html).

Jumlah tersebut semakin bertambah setiap tahunnya, sehingga pelanggaran akibat siswa sekolah yang menggunakan kendaraan pribadi semakin meningkat pula. Akibat dari pelanggaran tersebut banyaknya kecelakaan melibatkan siswa sekolah. Masalah lain mengenai banyaknya transportasi pribadi yang digunakan oleh siswa sekolah yakni terbatasnya lahan parkIr pada setiap sekolah. Rendahnya kualitas pelayanan angkutan umum menjadi salah satu faktor yang mendasari berbagai masalah transportasi di Kabupaten Tabanan.

Pemerintah Kabupaten Tabanan melalui Dinas Perhubungan mengeluarkan program angkutan siswa Trans Serasi (Sejahtera Aman dan Berprestasi) pada tahun 2014. Angkutan Kota Kabupaten Tabanan sudah beberapa tahun belakangan mati suri, karena tidak ada lagi kegairahan dirasakan oleh awak dan pengusaha Angkutan Kabupaten Tabanan serta tidak adanya penumpang bahkan menyebabkan beberapa trayek menghilang dari peredaran. Angkutan siswa bisa menjadi alternatif dan bahkan bisa menjadi cikal bakal usaha Pemerintah Kabupaten Tabanan untuk mempertahankan, membuat kajian strategis untuk memulihkan kondisi Angkutan Kabupaten Tabanan yang mati suri tersebut (Ayu, 2017).

Program Trans Serasi merupakan angkutan pedesaan yang disulap Pemkab Tabanan menjadi angkutan terpadu. Angkutan ini bertugas untuk mengantar siswa yang ada di
Tabanan secara gratis dan sebanyak 8932 siswa per harinya. Saat ini Pemkab Tabanan sudah memiliki 46 trayek dan 80 armada mobil angkutan yang melayani 7 kecamatan di Kabupaten Tabanan (https:// daerah.sindonews.com/Read/1323280/174/ Trans-Serasi-Pemkab-Tabanan-Jadi-Top-99Inovasi-Pelayanan-Publik-1532000779).

Bupati Tabanan Ni Putu Eka Wiryastuti mengemukakan, program ini merupakan salah satu strategi untuk meningkatkan taraf hidup sopir angkot. Kami tidak mematikan usaha angkot, justru kami berdayakan agar lebih baik dan kita ubah imagenya dimana dengan peran serta pemerintah angkot bisa menjadi layanan transportasi publik yang baik dan daya tarik untuk masyarakat. Angkotnya juga kami perbaiki dengan melakukan cat ulang, ban mobil kita ganti, sopir juga menggunakan seragam dan sopir angkot juga tidak boleh membawa mobil secara ugal-ugalan.

Kepala Dinas Perhubungan Kabupaten Tabanan I Made Agus Harthawiguna menambahkan, presentasi penurunan angka kecelakaan di Tabanan yang sukses menurun hingga tahun 2018. Sebelum adanya Trans Serasi tercatat ada 32 kasus kecelakaan yang melibatkan siswa per tahun. Setelah adanya program ini pada 2014 kecelakaan berkurang menjadi 23 kasus.

Pelaksanaaan angkutan siswa Trans Serasi ini dilakukan empat kali perjalanan yakni keberangkatan siswa sekolah pagi, keberangkatan siswa sekolah siang, penjemputan siswa sekolah pagi, dan penjemputan siswa sekolah siang. Adapun jumlah armada yang dioperasikan sampai tahun 2018 yakni ada 80 angkutan kota.

Penelitian terkait telah dikaji oleh (Sekarini \& Sudjana, 2018) yang berfokus pada perlindungan Hukum Bagi Pengguna Jasa Angkutan Trans Sarbagita Ditinjau Dari Undang-Undang Nomor 22 Tahun 2009 Tentang Lalu Lintas dan Angkutan Jalan. Hasil penelitian ini menunjukkan bahwa perlindungan hukum bagi pengguna jasa angkutan trans sarbagita ditinjau dari undang- undang angkutan jalan diatur dalam Undang-Undang Nomor 8 Tahun 1999 Tentang Perlindungan Konsumen, Undang-Undang Nomor 22 Tahun 2009 Tentang Lalu Lintas dan Angkutan Jalan, Peraturan Pemerintah Nomor 74 Tahun 2014 Tentang Angkutan Jalan, Peraturan Gubernur Bali Nomor 11 Tahun 2011 Tentang Standar Pelayanan Minimal Angkutan Umum TRANS SARBAGITA. Selanjutnya, (Bimaputra, 2018) juga melakukan penelitian serupa yang 
berfokus pada perlindungan hukum terhadap penumpang angkutan umum, studi pada taksi blue bird di kota denpasar. Hasil penelitian ini menunjukkan bahwa perlindungan hukum terhadap penumpang yang diberikan oleh blue bird yaitu memberi jaminan asuransi terhadap penumpang apabila mengalami kecelakaan dan tanggung jawab dari blue bird bersifat fault liability atau pertanggung jawaban karena kesalahan adalah seseorang baru dapat dimintakan pertanggung jawabannya secara hukum jika ada unsur kesalahan yang dilakukannya. dalam prinsip ini jelas bahwa setiap pengangkut harus bertanggung jawab serta mengganti rugi pihak yang dirugikan dan wajib membuktikan kesalahan pengangkut.

Agar lebih jelasnya permasalahan yang diteliti serta tercapainya tujuan penulisan dari penelitian hukum ini, maka perlu adanya penyusunan rumusan masalah yang telah diidentifikasi, sehingga dapat dirumuskan permasalahan dari penelitian yakni; 1 . Bagaimanakah upaya perlindungan hukum terhadap penumpang angkutan umum sebagai konsumen fasilitas transportasi? serta 2 . Bagaimanakah tanggung jawab pihak pengangkut terhadap kesalahan yang mengakibatkan kerugian bagi penumpang angkutan umum?

\section{Metode}

Penelitian ini dikategorikan ke dalam penelitian empiris, dikarenakan ingin mengetahui bentuk perlindungan hukum bagi penumpang Trans Serasi Tabanan. Penelitian ini menggunakan jenis pendekatan kualitatif, yaitu pendekatan yang digunakan berdasarkan pada data-data yang dinyatakan responden secara lisan atau tulisan, dan juga perilakunya yang nyata, diteliti dan dipelajari sebagai suatu yang utuh (Soerjono, 2001).

Dalam penelitian ini menggunakan metode pengumpulan data primer seperti Wawancara dengan pihak pengangkut, pihak pengguna jasa angkutan umum dan dari Dinas Pehubungan yang di lakukan dengan tujuan mempermudah proses penelitian dalam memperoleh hasil dari wawancara tersebut. Sedangkan metode pengumpulan data sekunder dalam penelitian ini diperoleh dari Dinas Perhubungan melalui dokumen mengenai jumlah angkutan umum Trans Serasi Tabanan. Selain itu juga dengan pengumpulan data melalui buku-buku literatur yang erat kaitannya dengan upaya perlindungan hukum bagi penumpang pada angkutan umum Trans Serasi Tabanan.

Metode analisa yang digunakan dalam penelitian ini adalah metode diskriptif kualitatif, yakni suatu metode analisa yang bertujuan untuk memperoleh suatu gambaran singkat mengenai suatu permasalahan yang tidak hanya berdasarkan atas angka-angka statistik saja, melainkan berdasarkan atas pengujian analisis melalui norma dan kaidah hukum yang berkenaan dengan permasalahan yang dibahas dalam penelitian ini.

Setelah data terkumpul kemudian dilakukan penarikan kesimpulan dengan menggunakan metode deduktif yakni suatu metode yang diawali dari hal-hal yang sifatnyat umum menuju ke hal-hal yang sifatnya khusus.

\section{Hasil dan Pembahasan}

\section{Upaya Perlindungan Hukum Terhadap Penumpang Angkutan Umum Sebagai Konsumen Fasilitas Transportasi}

Lalu lintas dan angkutan jalan merupakan sebagian dari sistem transportasi umum yang semestinya dilakukan suatu pengembangan potensi dan adanya peran dalam terwujudnya suatu keamanan, keselamatan, ketertiban dan kelancaran dalam berlalu lintas.

Keamanan disini di artikan sebagai suatu keadaan dimana terbebasnya setiap orang, barang, dan/ atau kendaraan dari gangguan perbuatan melawanhukum, dan/ atau rasa takut dalam berlalu lintas. Dengan terciptanya hal tersebut maka penumpang akan lebih terjamin keamanannya. Keselamatan yaitu suatu keadaan dimana terhindarnya setiap orang dari risiko kecelakaan selama berlalu lintas yangdisebabkan oleh manusia, Kendaraan, Jalan, dan/atau lingkungan. Dengan memperhatikan keselamatan maka penumpang juga tidak akan merasa was was ataupun ragu untuk menaiki angkutan umum tersebut.

Ketertiban adalah suatu keadaan berlalu lintas yang berlangsung secara teratur sesuai dengan hak dan kewajiban setiap Pengguna Jalan. Ketertiban juga sangat mempengaruhi penilaian dari penumpang apabila tertib dalam berlalu lintas maka penumpang pun merasa lebih aman sampai ke tempat yang dituju sebaliknya jika pengemudi yang tidak tertib dalam berlalu lintas seperti ugal -ugalan maka penumpang memberikan penilaian yang buruk dan bahkan kapok menaiki angkutan tersebut. Kelancaran adalah suatu keadaan berlalulintas dan penggunaan angkutan yang bebas dari hambatan dan kemacetan dijalan. Dengan terciptanya kelancaran maka pengemudi ataupun penumpang tidak akan menghabiskan 
waktu yang cukup lama dalam perjalanan.

Upaya yang telah di realisasikan Trans Serasi Tabanan yakni mengantar siswa yang ada di Tabanan secara gratis dan sebanyak 8932 siswa per harinya. Saat ini Pemkab Tabanan sudah memiliki 46 trayek dan 80 armada mobil angkutan yang melayani 7 kecamatan di Kabupaten Tabanan (https:// daerah.sindonews.com/Read/1323280/174/ Trans-Serasi-Pemkab-Tabanan-Jadi-Top-99Inovasi-Pelayanan-Publik-1532000779).

Program Trans Serasi Tabanan ini telah membantu masyarakat dalam meningkatkan taraf hidup khususnya bagi sopir angkot. Pemerintah tidak mematikan usaha angkot, justru memanfaatkannya agar menjadi lebih baik dan mengubahnya menjadi layanan transportasi publik yang baik dan menjadi daya tarik bagi masyarakat. Setelah adanya program ini pada 2014 kecelakaan berkurang menjadi 23 kasus yang awalnya terdapat 32 kasus.

Utamanya, program Trans Serasi Tabanan ini telah berupaya dalam menekan angka kecelakaan yang terjadi di Tabanan khususnya para pelajar SMP yang menggunakan kendaraan bermotor untuk pergi ke sekolah dan untuk memberikan kenyamanan dan menjamin keselamatan siswa saat berada dijalan raya, untuk mengurangi kemacetan yang ditimbulkan akibat meningkatnya volume kendaraan milik pribadi, serta untuk meningkatkan kualitas pelayanan angkutan umum yang mati suri.

\section{Tanggung Jawab Pihak Pengangkut Terhadap Kesalahan Yang Mengakibatkan Kerugian Bagi Penumpang Angkutan Umum}

Melihat pencapaian yang telah dilakukan oleh Trans Serasi Tabanan tersebut namun masih adanya salah satu kejadian yang menyebabkan kerugian bagi penumpang Trans Serasi Tabanan yakni dikutip dari wawancara dengan Aldi salah seorang penumpang Bahwa dia pernah mengalami kecelakaan saat menumpang trans serasi tabanan yaitu jatuh keluar dari pintu masuk angkutan yang disebabkan karena jumlah kapasitas penumpang yang berlebih sehingga mau tidak mau dia harus mengambil tempat yang seharusnya tidak wajar untuk di tumpangi seperti pintu keluar tersebut karena alasan tidak ada angkutan lagi dan mengejar waktu maka dia menumpang dalam keadaan angkutan ramai penumpang.

Analisa mengenai kasus tersebut bahwa termasuk ke dalam Hukum perdata yakni adanya ketentuan-ketentuan materiil yang mengatur satu orang individu dengan individuyang lain. Ketentuan tersebut yang mengatur hak-hak dan kewajiban seorang pengangkut dan seorang penumpang.

Dari definisi hukum perdata yang telah dijabarkan diatas maka kasus tersebut tergolong kasus hukum perdata karena hanya melibatkan satu orang individu dengan individu yang lain, lebih tepatnya antara pihak Pengangkut dengan pihak Penumpang.

Hukum perdata itu sendiri dibagi menjadi hukum perorangan yang memuat Peraturanperaturan tentang manusia sebagai subyek hukum serta peraturan-peraturan mengenai kecakapan untuk memiliki hak-hak dan untuk bertindak sendiri melaksanakan hak-haknya itu. Lalu ada hukum keluarga yang memuat perkawinan beserta hubungan dalam hukum kekayaan antara suami/ istri hubungan antara orang tua dan anak-anaknya, perwalian, pengampunan. Selain itu ada hukum harta kekayaan yang mengatur tentang hubunganhubungan hukum yang dapat dinilaikan dengan uang seperti hak mutlak yakni hak-hak yang berlaku terhadap tiap orang, sedangkan hak perorangan yakni hak-hak yang hanya berlaku terhadap seorang atau suatu pihak tertentu saja. Yang terakhir yakni hukum waris yakni mengatur tentang benda atau kekayaan seseorang jika ia meninggal dunia.

Dari penjabaran diatas, Analisa dari kasus tersebut masuk ke dalam kasus hukum perdata yakin bagian hukum Perorangan karena melibatkan pihak Pengangkut dengan pihak Penumpang.

Pendapat mengenai kasus tersebut bahwa masalah pokok pelanggaran lalu lintas sebenarnnya terletak pada faktor-faktor yang mungkin mempengaruhinya. Faktor tersebut mempunyai arti yang netral, sehingga dampak positif atau negatifnya terletak pada isi faktorfaktor tersebut. Seseorang yang melanggar peraturan lalu lintas, bukanlah selalu seorang yang dikatakan sebagai seorang penjahat melainkan seorang pengemudi yang melanggar lalu lintas adalah seseorang yang lalai di dalam membatasi penyalahgunaan hak-haknya. Memperluas trayek dan menambah jumlah armada dalam trayek tertentu yang dirasa padat penumpang dapat meminimalisir adanya pengemudi yang mengangkut penumpang dengan melebihi kapasitas.

Melalui proses wawancara yang dilakukan penulis dengan dinas perhubungan, dijelaskan pula mengenai upaya yang seharusnya dilakukan oleh dinas perhubungan apabila ada 
penumpang yang merasa dirugikan karena adanya kesalahan yang disebabkan oleh pihak pengangkut. Perwakilan dari Dinas Perhubungan menyampaikan bahwa pihak pengangkut harus bertanggungjawab terhadap kejadian yang telah merugikan pihak penumpang angkutan umum, maka pertanggung jawabannya bukan sekedar permohonan maaf saja tetapi harus dengan tanggungjawab yang nilainya setimpal yakni memberikan biaya santunan yang telah disepakati oleh PT. Jasa Raharja.

Dengan adanya asuransi kecelakaan tersebut maka pihak yang dirugikan dapat dipermudah dalam biaya pengobatannya namun yang dapat di pertanggung jawabkan oleh pihak jasa raharja sendiri yakni korban yang mengalami kecelakan dengan luka parah hingga meninggal dunia. Namun sampai saat ini Trans Serasi Tabanan tidak pernah tercatat adanya kecelakaan parah yang menyebabkan penumpang mengalami dampak kerugian serius, luka parah hingga hilangnya nyawa penumpang.

\section{Simpulan}

Berdasarkan analisis dan pembahasan dalam penulisan skripsi ini. Maka dapat ditarik beberapa kesimpulan Upaya hukum yang dapat dilakukan Pihak penumpang sebagai pengguna jasa yang merasa dirugikan yakni melalui dua cara yaitu upaya hukum diluar pengadilan yang dilakukan secara kekeluargaan (damai) dengan cara pihak penumpang sebagai pengguna jasa yang merasa dirugikan meminta pertanggungjawaban kepada pihak pengangkut dengan musyawarah antara kedua belah pihak. Sedangkan upaya hukum dengan melibatkan pengadilan dapat dilakukan oleh pihak penumpang dengan mengajukan ke kantor pengadilan setempat yang berwenang.

Dari kasus penelitian yang terjadi bahwa penumpang Trans Serasi Tabanan lebih memilih menggunakan penyelesaian masalah melalui jalur di luar pengadilan atau dalam bentuk mediasi atau secara kekeluargaan antara penumpang dan pengangkut dibandingkan penyelesaian masalah dengan menggunakan jalur pengadilan karena dirasa permasalahan yang terkait kasus tersebut bukanlah masalah yang besar dampaknya bagi penumpang atau menyebabkan penumpang mengalami luka parah bahkan menghilangkan nyawa penumpang.

Adanya Pertanggung jawaban atas kerugian penumpang yang diakibatkan oleh pihak pengangkut perihal penumpang yang mengalami kecelakaan seperti luka parah hingga merenggut nyawa penumpang dengan cara melibatkan Jasa Raharja sebagai perusahaan yang menyediakan dana pertanggungan wajib kecelakaan lalu lintas dengan nominal yang telah disepakati.

Namun Jasa Raharja akan melakukan pertanggung jawabannya apabila pihak penumpang mengalami kecelakaan dengan luka parah hingga menyebabkan hilangnya nyawa penumpang. Sedangkan untuk pertanggungjawaban bagi penumpang yang mengalami luka yang tidak parah maka pihak pengangkut memberikan tanggung jawab berupa pengobatan ringan baik di puskesmas terdekat hingga rumah sakit terdekat seperti terjadi lecet atau luka ringan yang masih bisa di atasi dengan biaya yang tidak terlalu mahal.

\section{Daftar Pustaka}

Ayu, D. W. U. D. (2017). Implementasi Program Angkutan Siswa Trans Serasi Dalam Meningkatkan Pelayanan Angkutan Siswa Gratis Di Kabupaten Tabanan. E-Jurnal Politika, 1(1). Retrieved from https://ojs.unud.ac.id/ index.php/politika/article/view/34910

Bimaputra, R. R. A. S. (2018). Perlindungan Hukum Terhadap Penumpang Angkutan Umum: Studi Pada Taksi Blue Bird Di Kota Denpasar. Notaire, 1 (1), 107. Retrieved from http:// dx.doi.org/10.20473/ntr.v1i1.9100

Sekarini, N. K. S., \& Sudjana, I. K. (2018). Perlindungan Hukum Bagi Pengguna Jasa Angkutan Trans Sarbagita Ditinjau Dari Undang-Undang Lalu Lintas dan Angkutan Jalan. Kertha Semaya, 6(4), 1 -6. Retrieved from https:// ojs.unud.ac.id/index.php/kerthasemaya/ article/view/29369

Soerjono, S. (2001). Sosiologi: Suatu Pengantar. Jakarta: Raja Grafindo Persada.

https://aerah.sindonews.com/ Read/1323280/174/Trans-SerasiPemkab-Tabanan-Jadi-Top-99-InovasiPelayanan-Publik-1532000779.

https://tabanankab.bps.go.id/ publication/2018/08/16/468aa965d1f1 fa d510484df3/kabupaten-tabanan-dalamangka-2018.html. 